\title{
Two variants of HIV-1 B serotype are transmitted heterosexually in São Paulo, Brazil
}

J. Casseb ${ }^{1}$, M.A. Hong ${ }^{1,2}$,

C. Gonsalez ${ }^{1}$, L.F. Brígido ${ }^{1,2}$,

A.J.S. Duarte ${ }^{1}$ and

R. M ichael-Hendry ${ }^{3}$

\author{
${ }^{1}$ Laboratório de Imunogenética e Transplante Experimental, \\ Faculdade de Medicina, U niversidade de São Paulo, São Paulo, SP, Brasil \\ Instituto Adolfo Lutz, São Paulo, SP, Brasil \\ ${ }^{3}$ Viral and Rickettsial Disease Laboratory, California Department of Health Services, \\ Berkeley, CA, USA
}

\section{Correspondence \\ J. Casseb \\ Laboratório de Imunogenética e \\ Transplante Experimental \\ Faculdade de Medicina, USP \\ Av. Dr. Arnaldo, 455 \\ 20 andar, Sala 2345 \\ 01246-903 São Paulo, SP \\ Brasil \\ Fax: + 55-11-881-7190 \\ E-mail: j31@ hotmail.com \\ Research partially supported by \\ Fogarty AIDS International \\ (TW\#00003) and by HC/FMUSP \\ LIM -56. \\ Publication supported by FAPESP.}

Received December 16, 1997 Accepted July 7, 1998

\begin{abstract}
HIV-1 variability may have an important impact on transmission and pathogenicity. Better characterization of the HIV epidemic in Brazil is necessary for the development of vaccine trials in this country. We analyzed sera from 108 HIV-1-infected volunteers from São Paulo City to determine serotype and reactivity for V3 motifs of HIV in this population, and the relationship to transmission mode. We concluded that the HIV-1 B serotype is frequent among heterosexually infected women, even in the absence of anal sex, and that two major V3 motifs, GPGR and GWGR, had similar prevalence among women $(48 \%$ and $52 \%$, respectively) and men (56\% and $44 \%$, respectively). We also observed an equal distribution of these strains regardless of their CD4+ T cell counts, clinical status, and mode of transmission. Even though V3 serology for HIV-1 subtyping is an inexpensive tool for use in developing countries, additional methods, such as heteroduplex mobility assay and direct DNA sequencing, should be included to determine HIV-1 genetic diversity.
\end{abstract}

In 1996, Soto-Ramirez et al. (1) demonstrated that in vitro tropism for Langerhans cells is a crucial pathway in HIV sexual transmission and that HIV clade (subtype) E had an increased tropism for Langerhans cells compared to clade B. They suggested that subtype $\mathrm{E}$ may be more transmissible through the female genital tract, which is rich in Langerhans cells. This would justify the prevalence of subtype E among heterosexuals in the Thailand epidemics. In contrast, since HIV subtype B does not show the same tropism for Langerhans cells, it would be expected to be more related to homosexual transmission, which is the main mode
Key words

- HIV

- Serotyping

- gp 120 V3 loop

- Synthetic peptides

- Sexual transmission

....................... of HIV transmission in the USA and Europe.

Brazil is the second country in the world in number of reported cases of AIDS (2) and $50 \%$ of all AIDS cases reported in Brazil in the last 15 years occurred in the State of São Paulo (3). Vulnerable groups include homosexual and bisexual men (32\%), intravenous drug users (IDU) (20\%), and heterosexuals (20\%), while $18 \%$ had unknown or other risk factors (3). The women to men ratio of reported AIDS cases has increased from 1:28 in 1983 , to $1: 3$ in $1996 / 97$. This ratio is $1: 1$ when only heterosexual males are included.

There are at least four different HIV-1 subtypes circulating in Brazil (B, F, C, D), 
and subtype B predominates (4-10). Recently, it was reported that two genetically and antigenically distinct strains of HIV-1 subtype B cocirculate in Brazil. One strain has the GPGR motif in the crown of the V3 loop region similar to that of US/European HIV-1 isolates, whereas the other has a GWGR motif, which is unique to isolates from Brazil $(6,9)$. We have analyzed the distribution of the two strains of HIV-1 subtype B with regard to clinical status (11), mode of transmission, and patient gender using a serologic test based on the V3 motif $(12,13)$. A crosssectional study was performed among HIV1-infected subjects participating in a study at the Immunology Division, Hospital das Clínicas, University of São Paulo, to evaluate the natural history of HIV infection in São Paulo.

A total of 108 subjects ( 85 men and 23 women) were analyzed. Median age was 33 years (range 20 to 66 years). Forty-six subjects were asymptomatic, 52 presented AIDS and no clinical data were available for 10 (11). Regarding risk factors for HIV infection, 56 patients were homosexual or bisexual men, 31 were heterosexuals ( $23 \mathrm{fe}-$ males and 8 males), 8 were IDU and 13 reported no risk factor. Four of the 23 women reported practicing anal sex, 15 denied this practice and no information with regard to this practice was available for 4 patients.

The EIA procedure was a modification of the method of Brostrom et al. (12). Briefly, microplates (Immulon II, round bottom) were coated with avidin DX (Vector Labs, Burlingame, CA) diluted in PBS, pH 7.4, at $10 \mu \mathrm{g} /$ $\mathrm{ml}$ overnight at $4^{\circ} \mathrm{C}$. Biotinylated peptides representing consensus sequences from the V3-region of consensus $\mathrm{B}, \mathrm{C}, \mathrm{F}$ and $\mathrm{MN}$, $\mathrm{SF} 2, \mathrm{BR} 1$, and BR2 strains (Figure 1) were diluted $1 \mu \mathrm{g} / \mathrm{ml}$ in PBS, $\mathrm{pH}$ 7.4, $0.1 \mathrm{ml} / \mathrm{well}$, and the plates were incubated overnight at $4^{\circ} \mathrm{C}$. The plates were washed five times with PBS plus $0.05 \%$ Tween-20 (PBS-T), blocked with PBS-T containing 5\% dry milk for $1 \mathrm{~h}$ at $37^{\circ} \mathrm{C}$ (Blotto), and washed five times with PBS-T. Serial 4-fold serum dilutions (0.1 $\mathrm{ml} /$ well) in Blotto were then added to the wells and incubated for $1 \mathrm{~h}$ at $37^{\circ} \mathrm{C}$. All assays included an HIV-1-positive human plasma pool as control. Each plate was run in duplicate and one plate was washed five times with PBS-T, while the other was washed five times with PBS- $8 \mathrm{M}$ urea. Peroxidase-labeled anti-human IgG (Kirkegaard and Perya, Thersburg, MD) diluted 1:10,000 in Blotto was added at $0.1 \mathrm{ml} /$ well and incubated for $1 \mathrm{~h}$ at $37^{\circ} \mathrm{C}$. The plates were washed 5 times with PBS-T, incubated with $0.15 \mathrm{ml} /$ well of TMB substrate for $30 \mathrm{~min}$ at room temperature, and the reaction was stopped with $0.05 \mathrm{ml} /$ well of $4 \mathrm{~N} \mathrm{H}_{2} \mathrm{SO}_{4}$. The plates were read at $450 \mathrm{~nm}$ and the endpoint titer was calculated as the interpolated dilution yielding a mean absorbance of 0.5 by linear regression. An avidity index was calculated as: (urea titer/PBS titer) x 100.

The specificity of the V3 peptide serotyping assay was determined using 41 sera
Figure 1 - Sequence of the gp120 V3 region of the synthetic peptides used. Dots indicate homology. All peptides contain biotin-SGSG at their amino terminus.

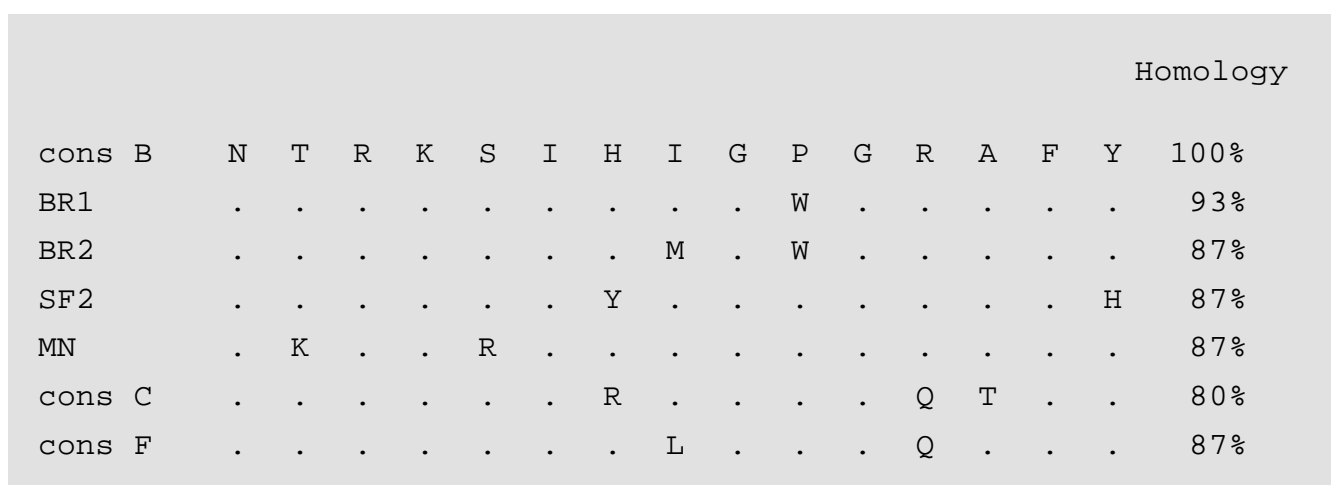


collected in São Paulo and Rio de Janeiro between 1983 and 1995 for which V3 sequences were available. A sum ratio is computed from the endpoint titers of four V3 peptides according to the formula: (BR1/ $\mathrm{SF} 2)+(\mathrm{BR} 1 / \mathrm{MN})+(\mathrm{BR} 2 / \mathrm{SF} 2)+(\mathrm{BR} 2 /$ $\mathrm{MN})=$ SUM. Sera with sums $<8$ are considered to represent infection with GPGR virus, those with sums $>16$ are considered to represent infection with GWGR virus and those with sums $\geq 8$ but $\leq 16$ are considered to be indeterminate.

Of the 22 sera typed as GPGR, 19 contained $\mathrm{P}$ at $\mathrm{V} 3$ residue 16 (numbering starts at the amino acid arginine), one contained $\mathrm{W}$, and two contained $\mathrm{L}$ or $\mathrm{T}$. Of the 13 sera typed as GWGR, 11 contained $\mathrm{W}$ at V3 residue 16 and two contained $\mathrm{L}, \mathrm{A}$, or T. Of the six sera typed as indeterminate, two contained $\mathrm{P}$ at $\mathrm{V} 3$ residue 16 , three contained $\mathrm{W}$, and one contained V. Of the 35 sera typed as either GPGR or GWGR, 30 (86\%) were correctly identified, four $(11 \%)$ contained other amino acids at $\mathrm{V} 3$ residue $16(\mathrm{~L}, \mathrm{~T}, \mathrm{~A}$, or V) and one typed as GPGR was actually GWGR by sequence.

In a previous study which included some samples from the present study, HIV-1 subtypes B and F were both present (9). In this study, serology revealed that most patients were infected by the B serotype. We did not observe statistical differences regarding clinical status or routes of transmission for clade $\mathrm{B}$ or for the B Brazilian variant (Table 1).

In Brazil at least four HIV-1 subtypes (B, $\mathrm{F}, \mathrm{C}$, and D) have been detected and there is also a report of a recombinant strain between subtypes B and F (6). We should emphasize that the EIA assay used by us does not discriminate between subtypes $\mathrm{B}$ and $\mathrm{F}$, and further improvement of the assay will be necessary to increase its specificity by using longer or alternative peptides based on Brazilian subtype F sequences.

The proportion of reactivity to peptides representative of GPGR and GWGR motifs in the tip of the V3 loop region was similar
Table 1 - Distribution of subtype B strains among HIV-1-infected subjects in São Paulo, Brazil.

The numbers in parentheses are percent. The V3 peptide EIA used in this study is not able to discriminate between subtypes B (GPGR motif) and F. Clinical status is based on CDC 1993 AIDS Revised Classification (11). IDU, Intravenous drug users

\begin{tabular}{lrrr}
\hline & \multicolumn{2}{c}{ N (\%) with indicated reactivity } \\
\cline { 2 - 4 } & GWGR & GPGR & Total \\
\cline { 2 - 4 } & & & \\
\hline Clinical status & & & \\
Asymptomatic & $25(54)$ & $21(46)$ & 46 \\
AIDS & $29(56)$ & $23(44)$ & 52 \\
Unknown & $4(40)$ & $6(60)$ & 10 \\
Gender & & & \\
Male & $46(56)$ & $39(44)$ & 85 \\
Female & $11(48)$ & $12(52)$ & 23 \\
Transmission & & & \\
Homosexual men & $23(57)$ & $17(43)$ & 40 \\
Bisexual men & $10(62)$ & $6(38)$ & 16 \\
IDU & $5(62)$ & $3(38)$ & 8 \\
Heterosexual & $17(52)$ & $14(48)$ & 31 \\
Unknown & $4(31)$ & $9(69)$ & 13 \\
Total & $59(55)$ & $49(45)$ & 108 \\
& & &
\end{tabular}

for patients of all groups, regardless of clinical status, modes of transmission and gender (Table 1).

In our study, 22 of 23 women were probably infected by heterosexual contact, and one was an IDU. This suggests that HIV-1 subtype B, with either GPGR or GWGR motifs, is transmitted heterosexually. This is in contrast to the findings of Soto-Ramirez et al. (1), who have suggested that subtype B is more likely to be transmissible by anal sex, and thus is more prevalent in homosexual men. Our findings are in keeping with those reported by Luppi (14), who found only HIV-1 subtype B by the heteroduplex mobility assay (HMA) among females attending an anonymous HIV testing center in São Paulo (13).

The current HIV/AIDS epidemic in Brazil is caused mostly by subtype B in São Paulo (9), with similar distribution of the two major variants (GWGR and GPGR V3 
motifs). These findings may be relevant in the event of an HIV-1 vaccine becoming available.

The EIA employed in this study is not able to distinguish between antibodies to subtypes B (GPGR) and F. Therefore, some subtype $F$ viruses may have been counted as $\mathrm{B}$ in our analysis. If this is the case, subtype $F$ viruses are likely to represent only a few cases, since its prevalence in different stud- ies has been found to be less than $25 \%$ of the viruses $(9,10)$. More accurate subtype distinction could be obtained by using a more specific assay, such as HMA. However, since HMA does not distinguish between subtype $B$ viruses with the GPGR motif and the GWGR motif, the EIA approach with V3 peptides must be used to specify the strain involved.

\section{References}

1. Soto-Ramirez LE, Renjifo B, McLane MF, Marlink R, O'Hara C, Sutthent R, Wasi C, Vithayasai $P$, Vithayasai $V$, Apichartpiyakul C, Auewarakul P, Cruz VP, Chui D-S, Osathanondh R, Mayer K, Lee T-H \& Essex M (1990). HIV-1 Langerhans' cell tropism associated with heterosexual transmission of HIV. Science, 271: 12911293.

2. World Health Organization (1997). AIDSglobal data. Weekly Epidemiological Records, 72: 357-360.

3. AIDS (1997). Boletim Epidemiológico. Ministério da Saúde/Programa Nacional de DST/AIDS, São Paulo. Ano X, No. 3.

4. Louwagie J, Delwart EL, Mullins JI, McCutchan FE, Eddy $G$ \& Burke DS (1994). Genetic analysis of HIV-1 isolates from Brazil reveals the presence of two distinct genotypes. AIDS Research Human Retroviruses, 10: 561-567.

5. Potts KE, Kalish ML, Lott $T$, Orloff $G$, Luo CC, Bernard MA, Alves CB, Badaro R, Suleiman J , Ferreira O, Schochetman G, J ohnson J r WD, Ou C-Y, Ho J L \& the Brazilian Collaborative Research Group (1993). Genetic heterogeneity of the V3 region of the HIV-1 envelope glycoprotein in Brazil. AIDS, 7: 1191-1197.

6. Morgado MG, Sabino EC, Shaer EG, Bongertz V, Brigido $L$, Guimarães $M L$, Castilho EA, Galvão-Castro B, Mullins J I, Hendry RM \& Mayer A (1994). V3 region polymorphisms in HIV-1 from Brazil: Prevalence of subtype B strains divergent from North American/European protype and detection of subtype F. AIDS Research Human Retroviruses, 10: 569-576.

7. Sabino EC, Shaer EG, Morgado MG, Korber BTM, Diaz RS, Bongertz V, Cavalcante S, Galvão-Castro B, Mullins J I $\&$ Mayer A (1994). Identification of human immunodeficiency virus type 1 envelope genes recombinant between subtypes B and $F$ in two epidemiologically linked individuals from Brazil. J ournal of Virology, 68: 6340-6346.

8. Couto-Fernandez J C, J anssens W, Heyndrickk L, Motte J , Fransen K, Peeters $M$, Delaporte E, Galvão-Castro B, Piot P \& Van Der Groen G (1994). Genetic and antigenic variability of HIV-1 type 1 in Brazil. AIDS Research Human Retroviruses, 10: 1157-1163.

9. Sabino EC, Diaz R, Brigido LF, Duarte AJ S, Meyer A \& Buscher M (1996). Distribution of HIV-1 subtypes seen in an AIDS clinic in São Paulo city, Brazil. AIDS, 10: 1579-1584.

10. M orgado MG, Guimarães ML, Gripp CBG, Costa Cl, Neves J r I, Veloso VG, LinharesCarvalho MI, Castelo-Branco LR, Bastos FT, Kuiken C, Castilho EA, Galvão-Castro B, Bongertz V \& HEC/Fiocruz AIDS Clin Res Group (1997). Detection of HIV-1 subtype D infection in Rio de J aneiro city,
Brazil, and absence of association between HIV-1 subtype distribution and exposure categories. Presented at the $2 \mathrm{nd}$ Brazilian Symposium of Basic Research on HIV/AIDS, Angra dos Reis, RJ , 7-10 September.

11. CDC: 1993 revised classification system for HIV infection and expanded surveillance case definition for AIDS among adolescents and adults (1992). Morbidity and Mortality Weekly Report, 41: 1-19.

12. Brostrom $C$, Sonnenberg $A \& \&$ Sallberg $M$ (1995). Human immunodeficiency virus (HIV) type 1-infected patients with no disease progression display high-avidity antibody production to autologous V3 sequences. J ournal of Infectious Diseases, 171: 509-511.

13. Hendry RM, Hanson CV, Bongertz $V$, Morgado M, Duarte A, Casseb J , Brigido L, Sabino E, Diaz R \& Galvão-Castro B (1996). Immunoreactivity of Brazilian HIV isolates with different V3 motifs. Memórias do Instituto Oswaldo Cruz, 91: 347348.

14. Luppi LG (1997). Fatores associados à infecção pelo HIV em mulheres atendidas no centro de orientação e aconselhamento do município de São Paulo. Master's thesis, Faculdade de Medicina, Universidade de São Paulo, São Paulo. 